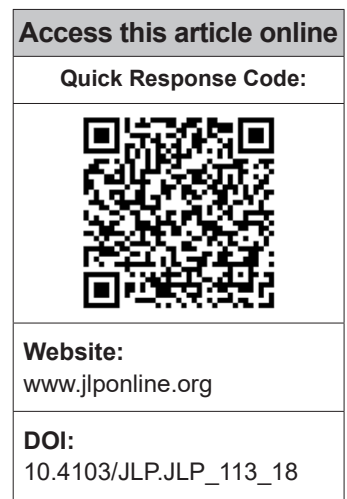

${ }^{1}$ Department of Microbiology, Bharath University, Chennai, ${ }^{4}$ Centre Research Laboratory, ICMR, Tirunelveli,

Tamil Nadu, Departments of ${ }^{2}$ Microbiology and ${ }^{5} / I^{r d}$ Year MBBS Student,

Sri Venkateshwara

Medical College and

Research Center,

${ }^{3}$ Department of

Microbiology, Centre for Research, Sri Lakshmi

Narayana Institute of Medical Sciences and Research, Puducherry, India

Address for correspondence:

Dr. E. Kavitha,

Bharath University,

Chennai, Tamil Nadu, India.

E-mail: kavimicro23@ gmail.com

Submission: 21-08-2018 Accepted: 23-11-2019

\title{
Bacteriological profile and perception on hand hygiene in school-going Children
}

\author{
E. Kavitha ${ }^{1,2}$, R. Srikumar ${ }^{3}$, G. Muthu ${ }^{4}$, T. Sathyapriya ${ }^{5}$
}

\section{Abstract:}

BACKGROUND: Handwashing is the most important daily activity to keep microbial infections at a distance. Schoolchildren tend to acquire most of the infections by not following the protocol of frequent handwashing which leads to frequent illnesses and absenteeism from school on a regular basis.

MATERIALS AND METHODS: A cross-sectional study was conducted by means of collecting hand swabs from 133 schoolchildren to estimate the extent of germs present. Furthermore, student's perception on hand hygiene was assessed by means of questionnaire.

RESULTS: Among the schoolchildren, majority (68.4\%) of them felt washing hands is important. Almost $56.4 \%$ of students washed their hands before eating lunch, but only $64.7 \%$ of them used soaps for cleaning their hands. Furthermore, hand swabs of 133 schoolchildren showed the growth of potential pathogens such as Staphylococcus aureus, Escherichia coli, Klebsiella spp., and Enterococcus faecalis.

CONCLUSIONS: Hands of schoolchildren were found to be contaminated and measures to inculcate the habit of frequent handwashing with soap are essential.

Key words:

Bacteriological profile, hand hygiene, student's perception, use of soap

\section{Introduction}

Tand hygiene plays a pivotal role Iin the containment of infectious diseases commonly circulating in home as well as in community. ${ }^{[1]}$ With greater advancements in medical knowledge and technology, human beings have come a long way, but still, there is a wide gap in the application of such vast knowledge in our day-to-day life. Contaminated hands act as a good source in spreading the commonly acquired respiratory and gastrointestinal diseases. ${ }^{[2]}$ Dr. Ignaz Semmelweis, in 1847 stated the importance of handwashing in reducing the transmission of puerperal fever. ${ }^{[3]}$

This is an open access journal, and articles are distributed under the terms of the Creative Commons Attribution-NonCommercial-ShareAlike 4.0 License, which allows others to remix, tweak, and build upon the work non-commercially, as long as appropriate credit is given and the new creations are licensed under the identical terms.

For reprints contact: reprints@medknow.com
Handwashing practice is comparatively poor in rural areas when compared with the urban population. Studies from various states in India report that large percentage of people in rural sectors do not wash their hands after cleaning child's bottom. Furthermore, among the rural population, the practice of washing hands with mud or ash instead of using soap is quite prevalent which, in turn, leads to many diseases. ${ }^{[4]}$

Studies showing the bacteriological profile among children are reported in many parts of the world as well as from India. ${ }^{[5,6]}$ These studies have reported fecal streptococci as the main contaminant. Also, Staphylococcus aureus and enteric pathogens are also commonly isolated pathogens from school going children. The spread of infectious agents as well as the spread of multiresistant pathogens is considered to be

How to cite this article: Kavitha E, Srikumar R Muthu G, Sathyapriya T. Bacteriological profile and perception on hand hygiene in school-going children. J Lab Physicians 2019;11:300-4. 
the main contributors to disease outbreaks due to hand contamination. ${ }^{[7]}$

Many initiatives have been taken by the WHO, the United Nations, to address the issue of improved hand hygiene practices by declaring 2008 as the International Year of Sanitation and October 15 as the Global Handwashing Day. ${ }^{[8-10]}$ In spite of many policies and protocols, studies report poor hand hygiene practices among students and health-care workers such as doctors, nurses, and medical students, across the world. ${ }^{[11]}$ Lack of facilities such as availability of soap all the time, alcohol-based hand rub dispensers, and liquid soap dispensers is also the key issue which varies from place to place to inculcate handwashing practices more efficiently.

As we wanted to report the prevalence of hand contamination among schoolchildren from this geographic region, the following objective was framed for the study: to understand the prevalence of bacteriological profile and the perception of school-going children about the importance of hand hygiene.

\section{Materials and Methods}

For the study, we chose a school located $10 \mathrm{~km}$ from our Institute (Sri Venkateshwara Medical college and Research Centre, Ariyur, Puducherry, India) at Kandamangalam, Tamilnadu, and 133 schoolchildren, aged approximately 9-12., i.e., in grades $6^{\text {th }}$ to $8^{\text {th }}$, were included in the study. The study was initiated after obtaining institutional ethical clearance and prior consent from the school administration.

For the sample collection, a station was established to collect the swabs aseptically. The dominant hand of the child was swabbed using the sterile moistened swab. Swabs were taken on a random basis and it was done by beginning from the wrist, followed by the palm area and finally leading up to all the five fingers which included the creases and the nail beds and ending in the dorsal aspects of the hand.

Perception about hand hygiene among school-going children was assessed by questionnaire devised in accordance with the WHO's guidelines in assessing the hand hygiene practices. The pro forma consisted of 25 questions mainly including multiple choices or "yes" or "no" questions. Washing hands before meal, washing hands with soap after using toilet, is failure to wash hand transmits infectious diseases, presence of handwashing station at school, presence of soap and water for handwashing at school and at home, etc., were the main questions asked to the school students.

The swabs were collected in Amies' Transport Media swabs (Himedia) and were transported to the laboratory within 1-2 h. In the laboratory, the swabs were inoculated on blood agar and MacConkey's agar and were examined for bacterial growth after 24-48 h of incubation. Pathogens were identified based on the colony morphology, gram staining, catalase test, coagulase test, mannitol fermentation, and biochemical reactions. All the isolates were screened for antimicrobial susceptibility testing by modified Kirby-Bauer disc-diffusion method as per the Clinical Laboratory Standards Institute Guidelines. S. aureus ATCC 25923 and Escherichia coli ATCC 25922 were used as the quality control.

\section{Data entry and analysis}

- Data were entered and analyzed by Epidata software version 2.2.2.186 (Epidata Association, Denmark, Europe) and by STATA analysis software version 11 (STATA Corp LLC, Texas, USA).

\section{Results}

A total of 133 schoolchildren were included in the study. Hand swabs were collected and details regarding hand hygiene were entered in structured questionnaire. Hand swabs were taken from all the included students which showed the growth of potential pathogens.

The following pathogens were identified following the culture and biochemical testing in the microbiology laboratory:

1. Coliforms such as E. coli, Klebsiella, and Enterobacter spp. mainly responsible for diarrheal diseases - detection by biochemical tests

2. S. aureus causing skin, respiratory, and also diarrheal diseases - detected by Gram-stain, coagulase, and catalase test

3. Salmonella and Shigella causing enteric and diarrheal diseases - detection by biochemical tests

4. Nonpathogenic commensals such as coagulase-negative staphylococci, diphtheroids, and Candida spp. - detected by colony morphology, Gram-stain, and coagulase test

5. Nonpathogenic environmental flora such as Micrococci and Bacillus spp. was detected by Gram-stain.

The most common pathogen isolated was S. aureus (19\%) which was many associated with skin and respiratory infections. Among the coliforms, E. coli $(20 \%)$ was the foremost pathogen followed by Klebsiella spp. (14\%) and Enterococcus faecalis (11\%). Few cultures showed the growth of commensal flora and some cultures showed no bacterial growth following $48 \mathrm{~h}$ of aerobic incubation [Tables 1 and 2].

The study included 133 school-going children who belonged to the age group of 9-12 years. Among the total 
participants, 83 (62.4\%) of children were male, whereas $50(37.6 \%)$ were female. Among all the study participants, $75(56.4 \%)$ were from urban areas, whereas 58 (43.6\%) belonged to the rural areas.

Table 1: Distribution of isolated organisms from the 133 hand swabs

\begin{tabular}{lc}
\hline Pathogens identified & Total (\%) \\
\hline Staphylococcus aureus & $25(19)$ \\
Escherichia coli & $27(20)$ \\
Klebsiella spp. & $18(14)$ \\
Enterococcus faecalis & $14(11)$ \\
Commensal flora & $42(31.5)$ \\
Sterile culture & $7(6)$ \\
\hline
\end{tabular}

When the data were analyzed by multivariate logistic regression analysis using STATA software, family occupation and parent's educational status were statistically significant. From the sociodemographic profiles of the schoolchildren, children whose parents belonged to farmer category showed significant association with proper handwashing (adjusted odds ratio [AOR]: 7.07, 95\% confidence interval [CI]: $[1.72,29.11])$. Similarly, schoolchildren whose parents were educated performed proper handwashing practice when compared with the uneducated category (AOR: 42.73, 95\% CI: [1.96, 929.37]) [Table 3].

Table 2: Factors affecting hand washing practice among schoolchildren $(n=133)$

\begin{tabular}{|c|c|c|c|c|c|}
\hline \multirow[t]{2}{*}{ Variables } & \multicolumn{3}{|c|}{ Hand washing practice } & \multirow[t]{2}{*}{ COR $(95 \% \mathrm{Cl})$} & \multirow[t]{2}{*}{ AOR $(95 \% \mathrm{Cl})$} \\
\hline & Total & Proper, $n(\%)$ & Improper, $\boldsymbol{n}(\%)$ & & \\
\hline \multicolumn{6}{|l|}{ Residency } \\
\hline Urban & 75 & $60(80)$ & $15(20)$ & $3.48(1.62-7.49)$ & $2.75(0.89-8.50)$ \\
\hline Rural & 58 & $31(53.45)$ & $27(46.55)$ & 1 & 1 \\
\hline \multicolumn{6}{|c|}{ Family occupation } \\
\hline Civil servant & 42 & $32(76.19)$ & $10(23.81)$ & $5.12(1.77-14.81)$ & $0.82(0.16-4.13)$ \\
\hline Farmer & 27 & $16(59.26)$ & $11(40.74)$ & $2.33(0.77-7.00)$ & $7.07(1.72-29.11)$ \\
\hline Shop owner & 38 & $33(86.84)$ & $5(13.16)$ & $10.56(3.09-36.07)$ & $2.89(0.58-14.32)$ \\
\hline Daily laborer & 26 & $10(38.46)$ & $16(61.54)$ & 1 & 1 \\
\hline \multicolumn{6}{|c|}{ Parent's educational status } \\
\hline Educated & 86 & $70(81.40)$ & $16(18.60)$ & $5.42(2.45-11.95)$ & $42.73(1.96-929.37)$ \\
\hline Uneducated & 47 & $21(44.68)$ & $26(55.32)$ & 1 & 1 \\
\hline \multicolumn{6}{|c|}{ Washing hands with soap after using toilet } \\
\hline Yes & 86 & $70(81.40)$ & $16(18.60)$ & $5.42(2.45-11.95)$ & 1 \\
\hline No & 47 & $21(44.68)$ & $26(55.32)$ & 1 & - \\
\hline \multicolumn{6}{|c|}{ Washing hands before meal } \\
\hline Yes & 75 & $60(80)$ & $15(20)$ & $3.48(1.62-7.49)$ & $0.64(0.05-8.38)$ \\
\hline No & 58 & $31(53.45)$ & $27(46.55)$ & 1 & 1 \\
\hline \multicolumn{6}{|c|}{$\begin{array}{l}\text { Can germs be acquired when desks, door, books, and } \\
\text { animals are touched? }\end{array}$} \\
\hline Yes & 92 & $68(73.91)$ & $24(26.09)$ & $2.22(1.02-4.80)$ & $0.79(0.16-3.87)$ \\
\hline No & 41 & $23(56.10)$ & $18(43.90)$ & 1 & 1 \\
\hline \multicolumn{6}{|c|}{ Do poor handwashing cause diseases? } \\
\hline Yes & 76 & $58(76.32)$ & $18(23.68)$ & $2.34(1.11-4.94)$ & $0.16(0.01-3.79)$ \\
\hline No & 57 & $33(57.89)$ & $24(42.11)$ & & 1 \\
\hline \multicolumn{6}{|l|}{ Knowledge } \\
\hline Insufficient & 53 & $27(60)$ & $23(43.40)$ & 1 & 1 \\
\hline Sufficient & 80 & 64 (72.73) & $19(23.19)$ & $2.46(1.16-5.20)$ & $1.18(0.05-29.99)$ \\
\hline \multicolumn{6}{|c|}{$\begin{array}{l}\text { You only need to wash your hands with soap if they look } \\
\text { dirty or smell bad? }\end{array}$} \\
\hline Yes & 97 & $84(70.59)$ & $26(26.80)$ & $2.18(0.98-4.84)$ & $2.22(0.45-11.03)$ \\
\hline No & 36 & $7(50)$ & $16(44.44)$ & 1 & 1 \\
\hline \multicolumn{6}{|c|}{ Presence of soap for handwashing } \\
\hline Yes & 72 & 49 (68.06) & $23(31.94)$ & $0.96(0.46-2.00)$ & $0.67(0.26-1.76)$ \\
\hline No & 61 & $42(68.85)$ & 19 (31.15) & 1 & 1 \\
\hline \multicolumn{6}{|c|}{ Presence of soap and water for handwashing at home } \\
\hline Yes & 94 & $65(69.15)$ & $29(30.85)$ & $1.12(0.50-2.48)$ & $0.83(0.29-2.41)$ \\
\hline No & 39 & $26(66.67)$ & $13(33.33)$ & 1 & 1 \\
\hline
\end{tabular}

$\mathrm{Cl}=$ Confidence interval, $\mathrm{COR}=$ Crude odds ratio, $\mathrm{AOR}=\mathrm{Adjusted}$ odds ratio 
Table 3: Antibiotic resistance pattern of Staphylococcus aureus $(n=25)$ for other antibiotics

\begin{tabular}{lc}
\hline Antibiotic & Resistant strains, $\boldsymbol{n}(\%)$ \\
\hline Penicillin $(10 \mathrm{units})$ & $25(100)$ \\
Amikacin $(30 \mu \mathrm{g})$ & $12(48)$ \\
Ciprofloxacin $(5 \mu \mathrm{g})$ & $10(40)$ \\
Co-trimoxazole $(1.25 / 23.75 \mu \mathrm{g})$ & $11(44)$ \\
Doxycycline $(30 \mu \mathrm{g})$ & $13(52)$ \\
Erythromycin $(15 \mu \mathrm{g})$ & $9(36)$ \\
Clindamycin $(2 \mu \mathrm{g})$ & $8(32)$ \\
Vancomycin E-strip & 0 \\
Linezolid $(30 \mu \mathrm{g})$ & 0 \\
Cefoxitin $(30 \mu \mathrm{g})$ & $13(52)$ \\
\hline
\end{tabular}

\section{Discussion}

Our study showed the presence of $64 \%$ of pathogenic bacteria on the hands of the schoolchildren. Isolation of these pathogens was similar from the existing Indian data where the commonly isolated pathogens were Staphylococcus spp., E. coli, Klebsiella spp., Proteus spp. Citrobacter spp., Streptococcus spp., Enterococcus spp., Pseudomonas spp., and Salmonella spp..$^{[2,6]}$

Our study showed a good proportion $(68.4 \%)$ of schoolchildren followed proper handwashing practice. The present findings of our study were found to be similar by a study done in Ethiopia, wherein more number of students $(99.0 \%)$ reported to follow handwashing before meals. ${ }^{[12]}$ Using soap for washing hands was found to be suboptimal in our study which was also in accordance with other studies done in various parts of the world. ${ }^{[13]}$

Accessibility of water and soap at school and at home all the time is a crucial factor. In our study, the unavailability of resources such as soap or handwash at school is a preventive factor for the students to inculcate proper handwashing practice. This finding was in line with other studies done from different parts of the world. ${ }^{[14,15]}$

As the isolated potential pathogens are the primary source of infections such as diarrhea, dysentery, and pneumonia, effective handwashing practices with clean water and with soap are very much essential. Such findings were supported by studies done in Kolkata, India, and in Karachi, Pakistan, which proved that washing hands with soap reduces the incidences of bacterial infections among school-going children. ${ }^{[16,17]}$

\section{Conclusions}

Hand contamination was observed among the schoolchildren, especially before taking their meals and after using toilets. Although frequent handwashing was observed by the schoolchildren, they hardly used soap for washing hands. Nonavailability of soap at the washing station and in the toilets was the reason for the contaminated hands among the schoolchildren.

Healthy habits should be inculcated from a young age which will motivate schoolchildren to continue hand hygiene practice into their adulthood also. However, due to the nonavailability of water and soap at the washing stations, inculcating such hygiene practices would not be possible.

\section{Acknowledgment}

The authors deeply acknowledge the support and cooperation of the participated school authority, schoolchildren, and teachers.

\section{Financial support and sponsorship}

Nil.

\section{Conflicts of interest}

There are no conflicts of interest.

\section{References}

1. Bloomfield SF, Aiello AE, Cookson B, O'Boyle C, Larson EL. The effectiveness of hand hygiene procedures in reducing the risks of infections in home and community settings including handwashing and alcohol-based hand sanitizers. Am J Infect Control 2007;35:27-64.

2. Ray SK, Amarchand R, Srikanth J, Majumdar KK. A study on prevalence of bacteria in the hands of children and their perception on hand washing in two schools of Bangalore and Kolkata. Indian J Public Health 2011;55:293-7.

3. Best M, Neuhauser D. Ignaz Semmelweis and the birth of infection control. Qual Saf Health Care 2004;13:233-4.

4. Ray SK, Dobe M, Maji S, Chakrabarty D, Sinha Roy AK, Basu SS. A pilot survey on hand washing among some communities of West Bengal. Indian J Public Health 2006;50:225-30.

5. Kyriacou A, Drakopoulou S, Georgaki I, Fountoulakis M, Mitsou E, Lasaridi KE, et al. Screening for faecal contamination in primary schools in Crete, Greece. Child Care Health Dev 2009;35:159-63.

6. Tambekar DH, Shirsat SD. Hand washing: A cornerstone to prevent the transmission of diarrhoeal infection. Asian J Med Sci 2009;1:100-3.

7. Pittet D, Allegranzi B, Boyce J, World Health Organization World Alliance for Patient Safety First Global Patient Safety Challenge Core Group of Experts. The World Health Organization Guidelines on Hand Hygiene in Health Care and their consensus recommendations. Infect Control Hosp Epidemiol 2009;30:611-22.

8. Kilpatrick C, Allegranzi B, Pittet D; WHO First Global Patient Safety Challenge: Clean Care is Safer Care. Contributing to the training of health-care workers around the globe. Int J Infect Control 2011;7:1-8.

9. Allegranzi B, Conway L, Larson E, Pittet D. Status of the implementation of the world health organization multimodal hand hygiene strategy in United States of America health care facilities. Am J Infect Control 2014;42:224-30.

10. World Health Organization. Guidelines on core Components of Infection Prevention and Control Programmes at the National and Acute Health care Facility Level. World Health Organization; 2016.

11. Pittet D, Mourouga P, Perneger TV. Compliance with 
handwashing in a teaching hospital. Infection Control Program. Ann Intern Med 1999;130:126-30.

12. Vivas AP, Gelaye B, Aboset N, Kumie A, Berhane $Y$, Williams MA. Knowledge, attitudes and practices (KAP) of hygiene among school children in Angolela, Ethiopia. J Prev Med Hyg 2010;51:73-9.

13. Curtis VA, Danquah LO, Aunger RV. Planned, motivated and habitual hygiene behaviour: An eleven country review. Health Educ Res 2009;24:655-73.

14. Ebong RD. Environmental health knowledge and practice survey among secondary schoolchildren in Zaria, Nigeria. Environ Health Perspect 1994;102:310-2.
15. Monse B, Benzian H, Naliponguit E, Belizario V, Schratz A, van Palenstein Helderman W. The Fit for School Health Outcome Study - A longitudinal survey to assess health impacts of an integrated school health programme in the Philippines. BMC Public Health 2013;13:256.

16. Luby SP, Agboatwalla M, Feikin DR, Painter J, Billhimer W, Altaf A, et al. Effect of handwashing on child health: A randomised controlled trial. Lancet 2005;366:225-33.

17. Sircar BK, Sengupta PG, Mondal SK, Gupta DN, Saha NC, Ghosh S, et al. Effect of handwashing on the incidence of diarrhoea in a Calcutta slum. J Diarrhoeal Dis Res 1987;5:112-4. 